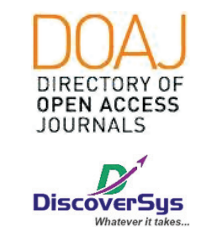

Published by DiscoverSys

\section{The characteristic of anxiety and depression among medical students at the Faculty of Medicine, Universitas Udayana, Bali in 2016}

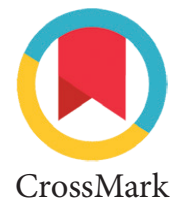

Tharshani Devi Srinivasagam, ${ }^{1 *}$ Bagus Komang Satriyasa ${ }^{2}$

\title{
ABSTRACT
}

Background: Anxiety and depression are some of the most prevalent mental health problems, especially among medical students. This study aims to evaluate the severity of anxiety and depression and also the prevalence of anxiety and depression faced by the students of the Medical Faculty, Universitas Udayana, Bali, Indonesia

Methods: A retrospective cross-sectional study was conducted among 95 medical students from the Faculty of Medicine, Universitas Udayana, Bali, Indonesia, during January-December 2016. The variables assessed in this study were gender, nationality, the severity of anxiety and depression, frequency, causes, symptoms, and medication usage in this study. Data were analyzed using SPSS version 20 for Windows.
Results: The characteristic of anxiety and depression among medical students was predominant in female (55.8\%), Indonesian students $(57.9 \%)$, mild severity $(89.5 \%)$, once in two weeks of frequency $(52.6 \%)$, and exam as the primary causes (91.6\%). Besides, most symptoms of anxiety and depression were headache (100.0\%) following by paracetamol usage (94.7\%) as medication.

Conclusion: Several characteristics of anxiety and depression found among medical students were primarily related to the female Gender, Indonesian students, exam as the primary causes, headache symptoms, and paracetamol as the main medication uses to relieve the symptoms.
${ }^{1}$ Undergraduate Student, Faculty of Medicine, Universitas Udayana, Bali, Indonesia

${ }^{2}$ Department of Pharmacology, Faculty of Medicine, Universitas Udayana, Bali, Indonesia
${ }^{*}$ Correspondence to: Tharshani Devi Srinivasagam, Undergraduate Student, Faculty of Medicine, Universitas Udayana, Bali, Indonesia tharshanidevi@gmail.com

Received: 2019-09-01 Accepted: 2020-06-30 Published: 2020-08-01

Keywords: Anxiety, Depression, Characteristics, Medical Students

Cite This Article: Srinivasagam, T.D., Satriyasa, B.K. 2020. The characteristic of anxiety and depression among medical students at the Faculty of Medicine, Universitas Udayana, Bali in 2016. Intisari Sains Medis 11(2): 643-646. D0I: 10.15562/ism.v11i2.600

\section{INTRODUCTION}

Anxiety is a normal reaction to stress and can be beneficial in some dangerous situations. ${ }^{1}$ However, if the anxiety is causing the disturbance and limitation in performing daily activity, it can be classified as an anxiety disorder. ${ }^{1}$ According to DSM V, general anxiety disorder defined as the excessive anxiety occurring more days than not for at least 6 months about a number of events or activities. ${ }^{2}$ The symptoms include restlessness, feeling keyed up on edge, being easily fatigued, difficulty concentrating or mind going blank, irritability, muscle tension, and sleep disturbance. ${ }^{3}$ On the other hand, depression is defined by experiencing at least one of symptoms such as diminished interest or pleasure, significant weight loss, slowing down of thought, feeling the worthless diminished ability to think or concentrate, and recurrent thought of death and suicide at least for more than 2 weeks. ${ }^{4}$

According to large population-based surveys, the global prevalence of anxiety disorder is $33.3 \%$ approximately, whereas depression is about $28.7 \% .^{5}$ Studies that include 44 countries estimated that the current prevalence is between a range of $2.4 \%$ until $29.8 \%$, the highest prevalence hold by European countries, and the lowest belong to African and Asian countries., Even though Asian is one of the countries with the lowest prevalence of anxiety disorder, some study conducted in Indonesia shows that among 628.800 people with a mental disorder in Indonesia, around $6.0 \%$ of them have the symptoms of depression and anxiety which was about 37.328 people. $^{7}$

One of the populations that are prone to have depression and anxiety disorder is medical students. ${ }^{8,9}$ The prevalence of anxiety among medical students is quite high. ${ }^{9}$ One study report that $35.5 \%$ and $32.8 \%$ of medical students proved to have anxiety and depression higher prevalence among women. ${ }^{10}$ Another study shows that the prevalence rate of depression and anxiety among medical students was $29.2 \%$ and $22.4 \%$. Females were more likely to have medium to severe anxiety compared to men. ${ }^{11}$ Some factors cause anxiety among medical students, such as parent's pressured, having non-physician parents, concerns about their future and the academical pressure itself. ${ }^{10}$ A latest study in Turkey also shows that $35.8 \%$ of 928 medical students experienced mild and moderate levels of anxiety and stress with the most prevalent among first-year medical students. ${ }^{12}$ It was also 1.9 times higher among female students compared to the male student. ${ }^{12}$ On the other hand, they found $30.5 \%$ of students have mild-moderate depression and $8.5 \%$ have severe depression. ${ }^{12}$ 
Anxiety and depression among medical students deserve more attention since it can influence student academic performance. A study from Hakami et al. shows that anxiety and depression among medical student has a significant correlation with work and social life disabilities. ${ }^{13}$ It also affects their actual physical health that contributes to their low academic performance. ${ }^{13}$ Another similar study reports that medical student's final score significantly decline with the existence of anxiety compared to normal students. ${ }^{14}$ Anxiety among medical students most likely to coexist with depression and students with both anxiety and depression will have a significant decline of the average final score. ${ }^{14}$

Based on the mentioned above, this study aims to evaluate the characteristics of anxiety and depression among medical students at the Faculty of Medicine, Universitas Udayana, Bali, Indonesia. It is hoped that student awareness about anxiety and depression will improve; thereafter, seeking help to improve their quality of life will be more frequent among them.

\section{METHOD}

This study used a descriptive observational study with a cross-sectional approach. The study was conducted at Medical Faculty Udayana University from January to December 2016. Students who refused to join the study were excluded from this study. This study using a questionnaire to assess anxiety and depression among medical students. The variable that was evaluated in this study were gender (male and female), nationality (Indonesian and Malaysian), severity (Mild, Moderate, and Severe), frequency (once or twice a week, once in more than a week, and once in two weeks), causes (exam, family issues, and peer pressure), clinical symptoms (Headache, loss appetite, sleeping problem, and difficulty concentrating), and medication (Paracetamol, antidepressant, counseling, and sleeping pills) that they used for the anxiety and depression.

The severity of anxiety was measured Hamilton Anxiety Rating Scale (HAM-A), and depression was assessed by the Hamilton Depression Rating Scale (HAM-D) valid and reliable questionnaire. Data were tabulated and analyzed using SPSS version 20 for Windows.

\section{RESULT}

Female was more prevalent than males ( $55.8 \%$ vs. 44.2\%) (Table 1). More than half of them (57.9\%) were Indonesian, and the other was Malaysian. The vast majority of them suffered from mild anxiety and depression. Most of them experienced symptoms once in two weeks (52.6\%). The symptoms that they were reported to include headache (100.0\%), loss appetite (47.4\%), sleeping disturbance (78.9\%) and concentrating difficulties (63.2\%) (Table 1). The most common cause of depression and anxiety among them was exam stress (91.6\%). There were only $36,8 \%$ of them who get help by doing counseling. Most of them took paracetamol to make the symptoms better (94.7\%) (Table 1).

\section{DISCUSSION}

This study shows that the prevalence of anxiety and depression was $36,1 \%$. This result is similar to the

\section{Table 1 Demographic Characteristics of} the Patients

\begin{tabular}{|c|c|}
\hline Variables & $\begin{array}{l}\text { Frequency } \\
(\mathrm{N}=95)\end{array}$ \\
\hline \multicolumn{2}{|l|}{ Gender, n (\%) } \\
\hline Male & $42(44,2)$ \\
\hline Female & $53(55,8)$ \\
\hline \multicolumn{2}{|l|}{ Nationality, n (\%) } \\
\hline Indonesian & $55(57,9)$ \\
\hline Malaysian & $40(42,1)$ \\
\hline \multicolumn{2}{|l|}{ Severity, n (\%) } \\
\hline Mild & $85(89,5)$ \\
\hline Moderate & $4(4,2)$ \\
\hline Severe & $6(6,3)$ \\
\hline \multicolumn{2}{|l|}{ Frequency, n (\%) } \\
\hline Once a week & $30(31,6)$ \\
\hline Twice a week & $10(10,5)$ \\
\hline Once in more than a week & $5(5,3)$ \\
\hline Once in two weeks & $50(52,6)$ \\
\hline \multicolumn{2}{|l|}{ Causes, n (\%) } \\
\hline Exam & $87(91,6)$ \\
\hline Family issues & $5(5,2)$ \\
\hline Peer Pressure & $3(3,2)$ \\
\hline \multicolumn{2}{|l|}{ Symptoms, n (\%) } \\
\hline Headache & $95(100.0)$ \\
\hline Loss of appetite & $45(47,4)$ \\
\hline Sleeping problem & $75(78,9)$ \\
\hline Difficulty concentrating & $60(63,2)$ \\
\hline \multicolumn{2}{|l|}{ Medication, n (\%) } \\
\hline Paracetamol & $90(94,7)$ \\
\hline Antidepressant & $30(31,2)$ \\
\hline Counseling & $35(36,8)$ \\
\hline Sleeping pills & $10(10,5)$ \\
\hline
\end{tabular}


other similar study among medical students where the prevalence also around $30 \% .{ }^{11,12}$ The tendency of female students to get anxiety and depression also similar to previous studies. ${ }^{11,12}$ The differences tendency among Gender brought some researchers to have a further examination for it. Some studies found that both prenatal and postnatal mechanisms play a role behind it. The exposure of fetal sex hormones create clear differences in Hypothalamic Pituitary Adrenal (HPA)-axis regulations, which play a special role in mental disorder, especially depression and anxiety. ${ }^{15}$ It is believed that a surge level of estrogen before menstruation among female create a tendency for them to have depression and anxiety. ${ }^{16}$ It was proven by a less effective use of antidepressant medication during the pre-menstrual cycle. ${ }^{17,18}$ Other study also suggests that testosterone have a protective effect on depression and anxiety. ${ }^{19}$ The role of this androgen known since there was a higher likelihood of developing anxiety and depression among males during the consumption of androgen depleting medication. ${ }^{19}$ Testosterone is known to have an effect of enhancing dopamine release in the mesolimbic system, which protects against depression. Its metabolic product can interact with serotonin 5 -HT3 receptor that creates anti-depressant effects. ${ }^{19,20}$

In this study, the most common cause of anxiety and depression was exam stress. This is similar to the study conducted by Patil SG and Aithala M that shows the significant effect of continuous examination with anxiety and depression within first-year medical students. ${ }^{21}$ Some of them also get anxiety for negative and irrational thinking about exams significantly. ${ }^{21}$ Other students who came from other places were also significantly feel anxiety and depression from being away from their families. ${ }^{21}$ That study clearly stated that exams are one of the stressors that can trigger both anxiety and depression.

\section{CONCLUSION}

The prevalence of depression and anxiety among Udayana University medical students was $36,1 \%$ with female dominations. Most of them experienced mild symptoms include headache, loss of appetite, sleep disturbances, and difficulties concentrating at least once a week. Less than half of them who doing counseling for their symptoms. Most of them only took paracetamol to improve their symptoms.

\section{CONFLICT OF INTEREST}

There is no competing interest regarding the manuscript.

\section{ETHICS CONSIDERATION}

Ethics approval has been obtained prior to the study being conducted from the Ethics Committee, Faculty of Medicine, Universitas Udayana, Bali, Indonesia.

\section{FUNDING}

None.

\section{AUTHOR CONTRIBUTION}

Both authors are equally contributed to the study from the conceptual framework, data gathering, data analysis until reporting the results of study through publication.

\section{REFERENCES}

1. Thibaut F. Anxiety disorders: a review of current literature. Dialogues Clin Neurosci. 2017;19(2):87-88.

2. Kupfer DJ. Anxiety and DSM-5. Dialogues Clin Neurosci. 2015;17(3):245-246

3. Rose M, Devine J. Assessment of patient-reported symptoms of anxiety. Dialogues Clin Neurosci. 2014;16(2):197-211.

4. Smith KM, Renshaw PF, Bilello J. The diagnosis of depression: current and emerging methods. Compr Psychiatry. 2013;54(1):1-6.

5. Baxter AJ, Scott KM, Vos T, Whiteford HA. Global prevalence of anxiety disorders: a systematic review and meta-regression. Psychol Med. 2013;43(5):897-910.

6. Bandelow B, Michaelis S. Epidemiology of anxiety disorders in the 21st century. Dialogues Clin Neurosci. 2015;17(3):327-335.

7. Ayuningtyas D, Misnaniartu, Rayhani M. Analisis Situasi Kesehatan Mental pada Masyarakat di Indonesia dan strategi Penganggulangannya. Jurnal Ilmu Kesehatan Masyarakat. 2018;9(1):1-10.

8. Moir F, Yielder J, Sanson J, Chen Y. Depression in medical students: current insights. Adv Med Educ Pract. 2018;9:323-333.

9. Quek TT, Tam WW, Tran BX, et al. The Global Prevalence of Anxiety Among Medical Students: A Meta-Analysis. Int J Environ Res Public Health. 2019;16(15):2735.

10. Tabalipa F, Souza M, Pfutzenreuter G, Lima V, Trabert E, Traebert J. Prevalence of Anxiety and Depression among Medical Students. Revista Brasileira De Educacao Medica. 2015;39(3):388-394.

11. Adhikari A, Dutta A, Sapkota S, Chapagain A, Aryal A, Pradhan A. Prevalence of poor mental health among medical students in Nepal: a cross-sectional study. BMC Med Educ. 2017;17(1):232.

12. Ediz B, Ozcakir A, Bilgel N. Depression and anxiety among medical students: Examining scores of the beck depression and anxiety inventory and the depression anxiety and stress scale with student characteristics. Cogent Psychology. 2017;4:128-133.

13. Hakami RM, Mahfouz MS, Adawi AM, et al. Social anxiety disorder and its impact in undergraduate students at Jazan University, Saudi Arabia. Ment Illn. 2018;9(2):7274.

14. Mihailescu A, Ciobanu A, Diaconescu L, Donisan T. The impact of anxiety and depression on undergraduate medical students. European Psychiatry. 2016;12(1):27-33.

15. Goldstein JM, Holsen L, Handa R, Tobet S. Fetal hormonal programming of sex differences in depression: linking women's mental health with sex differences in the brain across the lifespan. Front Neurosci. 2014;8:247. 
16. Walf AA, Frye CA. A review and update of mechanisms of estrogen in the hippocampus and amygdala for anxiety and depression behavior. Neuropsychopharmacology. 2006;31(6):1097-1111.

17. Altemus M, Sarvaiya N, Neill Epperson C. Sex differences in anxiety and depression clinical perspectives. Front Neuroendocrinol. 2014;35(3):320-330.

18. Donner NC, Lowry CA. Sex differences in anxiety and emotional behavior. Pflugers Arch. 2013;465(5):601-626.

19. McHenry J, Carrier N, Hull E, Kabbaj M. Sex differences in anxiety and depression: role of testosterone. Front Neuroendocrinol. 2014;35(1):42-57.

20. Soetrisno S, Cahyanto E, Mulyani S, Nugraheni A, Nurinasari H, Tjiang R. The cortisol level, depression anxiety stress score, and quality of life in patient with advance stage cervical cancer after two years of psychorative intervention. Bali Medical Journal. 2020;9(1):6-12.
21. Patil SG, Aithala M. Exam anxiety: Its prevalence and causative factors among indian medical students. National Journal of Phsysiology Pharmacy and Pharmacology. 2017;7(12):1-6.

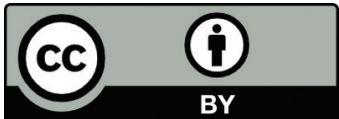

This work is licensed under a Creative Commons Attribution 